\title{
Health-related quality of life after stroke
}

\author{
Qualidade de vida relacionada à saúde de pessoas \\ após acidente vascular cerebral
}

\author{
Mary Ângela de Oliveira Canuto ${ }^{1}$ \\ Lídya Tolstenko Nogueira ${ }^{1}$ \\ Telma Maria Evangelista de Araújo ${ }^{1}$
}

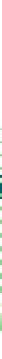

\section{Keywords}

Quality of life; Stroke; Nursing research;

Public health nursing

Descritores

Qualidade de vida; Acidente vascular cerebral; Pesquisa em enfermagem;

Enfermagem em saúde pública

Submitted
October 14, 2015
Accepted
June 6, 2016

Corresponding author

Mary Ângela de Oliveira Canuto

Campus Universitário Ministro

Petrônio Portella, 64049-550,

Teresina, PI, Brazil.

maryangela.canuto@yahoo.com.br

DOI

http://dx.doi.org/10.1590/1982-

0194201600035

\section{Abstract}

Objective: To assess health-related quality of life after stroke and associate this event with the characteristics of people who suffered a stroke.

Methods: Cross-sectional study conducted at a rehabilitation center for stroke survivors with 104 patients. The Mini-mental state examination (MMSE); an instrument for collection of sociodemographic, economic, clinical, and family related information; and the Stroke Specific Quality of Life Scale were applied.

Results: Of the 104 people investigated, 77 did not have cognitive deficit and answered the instruments. Their mean at the MMSE was 24.9 ( \pm 4.3$) .51 .9 \%$ were men and their mean age was $57.3( \pm 17.2)$ years. Most of them were married (48.1\%) and had eight or more years of schooling $(50.7 \%)$. Their health-related quality of life was affected (146.8 \pm 36.3$)$, mainly in the social and family relations domains.

Conclusion: An impairment in the health-related quality of life and negative consequences of the stroke were observed, together with dyslipidemia, left-side hemiplegia, and speech difficulty.

\section{Resumo}

Objetivo: Avaliar a qualidade de vida relacionada à saúde de pessoas após acidente vascular cerebral e associar esse evento às características desses indivíduos.

Métodos: Estudo transversal realizado em centro de reabilitação com pessoas sobreviventes de acidente vascular cerebral com 104 pacientes. Foram aplicados Miniexame do Estado Mental; instrumento para coleta de informações sociodemográficas, econômicas, do arranjo familiar e clínicas; e Stroke Specific Quality of Life Scale.

Resultados: Das 104 pessoas investigadas, 77 não apresentaram défice cognitivo e responderam aos instrumentos. A média no Miniexame do Estado Mental foi 24,9 ( $\pm 4,3) ; 51,9 \%$ eram homens, a média da idade foi $57,3( \pm 17,2)$ anos, a maioria era casada $(48,1 \%)$, com 8 anos ou mais de estudo $(50,7 \%)$. A qualidade de vida relacionada à saúde foi afetada $(146,8 \pm 36,3)$, principalmente nos domínios relações sociais e familiares. Conclusão: Evidenciaram-se comprometimento da qualidade de vida relacionada à saúde e consequências negativas da doença, associadas à escolaridade, dislipidemia, hemiplegia esquerda e dificuldade de fala.
${ }^{1}$ Universidade Federal do Piauí, Teresina, PI, Brazil.

Conflicts of interest: there are no conflicts of interest to declare. 


\section{Introduction}

Strokes are the second death cause in the world. Projections show that one in every six people will have a stroke in life; 15 million people suffer a stroke per year and 6 million do not survive. Among those who do survive, most have residual impairments. ${ }^{(1)}$

Such sequelae make individuals partly or totally handicapped and have serious implications for their quality of life because of years lost in productive life, additionally to the high financial costs involved. ${ }^{(2)}$

The term "health-related quality of life" is commonly used with similar objectives to the more general concept of quality of life. However, quality of life has a broader definition, influenced by sociological studies that do not allude to illnesses and impairments, whereas health-related quality of life seems to refer to aspects that are more directly related to illnesses or health care interventions. ${ }^{(3)}$ Research shows a decay in the domains and quality of life related to post-stroke health. ${ }^{(4-6)}$

Based on the aforementioned facts, the objective of this study was to assess health-related quality of life in people who suffered a stroke and connect this event to these individuals' characteristics.

\section{Methods}

A cross-sectional study was conducted between February and August, 2014, at the rehabilitation center Centro Integrado de Reabilitação de Teresina, in the state of Piauí, northeast Brazil. This center is a non-profit institution dedicated to the rehabilitation of disabled people.

The population consisted of 255 patients who were seeking post-stroke rehabilitation in 2014 . Simple random sampling was used and the sample calculation took into account a tolerable error of $6 \%$, with a $95 \%$ significance level that resulted in 132 participants.

After applying inclusion criteria (age $\geq 18$ years and confirmed stroke diagnosis) and exclusion criteria (neurological comorbidity and language con- straints that would prevent individuals from answering the questions), the sample had 104 patients. The Mini-mental state examination (MMSE) was used for cognitive tracing to assess whether an individual had the necessary understanding to answer the questions in the additional instruments, with a sample loss of 27 participants who did not have this prerequisite (Figure 1).

The research instruments used were: the MMSE to assess cognitive functions and select individuals who were capable of answering the other instruments; a structured script to obtain sociodemographic and economic data, in addition to family and health related information; and the Stroke Specific Quality of Life Scale (SS-QOL).

The MMSE is one of the most commonly used scales for cognitive assessment. It assesses the domains of orientation to time, orientation to place, registration, attention and calculation, recall, language, repetition, and complex commands. ${ }^{(7)}$ Its scoring goes from zero (higher degree of cognitive impairment) to 30 points (best capability), and cut-off scores are adjusted according to schooling: 13 points for illiterates, 18 for low schooling (1 to 4 years, unfinished) and average schooling ( 4 to 8 years, unfinished), and 26 for high schooling (8 or more years) - which were the recommendations adopted in this study. ${ }^{(8)}$

The SS-QOL is a specific instrument to assess health-related quality of life among people who suffered a stroke, which was culturally validated and adapted to Brazil. ${ }^{(9,10)}$ It lists 49 items in 12 domains and its scoring goes from 49 to 245 points. Answers vary from 1 to 5 points; higher figures indicate better health-related quality of life. ${ }^{(6,9)}$

Techniques of descriptive and inferential statistics were applied and the software Statistical Package for the Social Sciences, version 18.0, was used. For categorical variables, absolute and percentage frequencies were measured; for numerical variables, means and standard deviations were calculated. Means between health-related quality of life scores and groups categorized according to qualitative variables were associated by means of the Student's t test of two independent samples (dichotomy variables) and the Analysis of Variance 


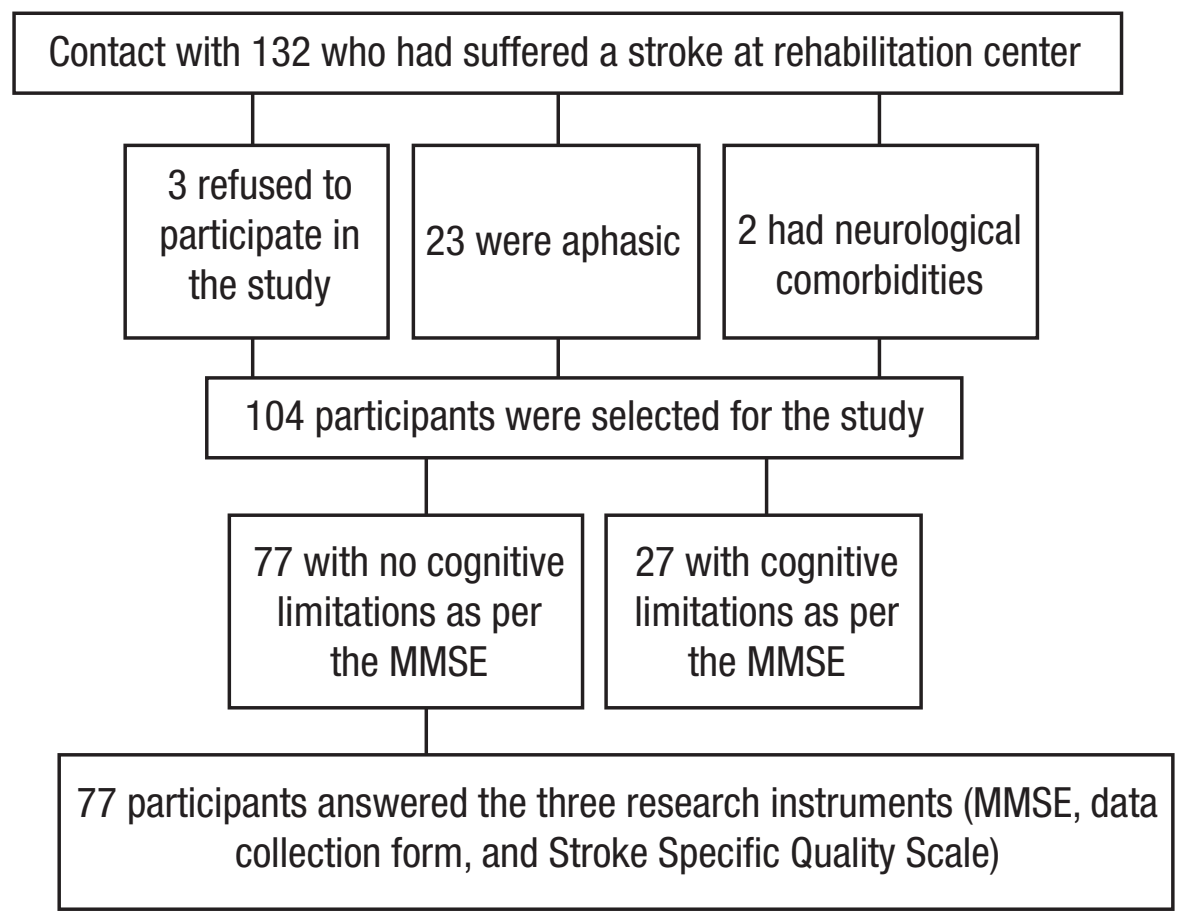

MMSE-Mini-Mental State Examination

Figure 1. Flowchart of study participants'selection

(ANOVA, for variables with more than two categories with the post hoc test, Tukey's correction).

To test the correlation between continuous quantitative variables, Pearson's correlation coefficient was used for normal distribution variables and its nonparametric correspondent, Spearman's correlation, was used for non-normal distribution data. An alpha 0.05 level of significance was used for all the analyses conducted $(\mathrm{p} \leq 0.05)$.

This study was registered into the Plataforma Brasil under Certificate of Presentation for Ethical Appreciation (CAAE, as per its acronym in Portuguese) number 21885513.4.0000.5214.

\section{Results}

Initially, the MMSE ( $\mathrm{n}=104)$ was applied and the mean was 23.1 points $( \pm 5.54)$. Considering the cutoff score adjusted according to schooling, $26 \%$ of the sample had cognitive deficit and, for that reason, these individuals did not proceed on to the additional stages.

Among the people without cognitive deficit $(\mathrm{n}=77)$, the mean scoring on the MMSE was 24.9 $( \pm 4.3) .51 .9 \%$ of respondents were men; their mean age was 57.3 years $( \pm 17.2)$; the majority was married $(48.1 \%)$, with eight or more years of schooling (50.7\%) and low income (Table 1).

All the dimensions evaluated by the SS-QOL suffered a decline. The most impaired domains were social relations (2.1) and family relations (2.4). The least impaired were sight (4.3) and language (3.8) (Table 2).

There was a positive moderate association between the MMSE scores and health-related quality of life. As for the variables schooling, dyslipidemia, left hemiplegia, and difficulty of speech, they interfered negatively on health-related quality of life (Table 3). 
Table 1. Characteristics of people who suffered a stroke $(n=77)$

\begin{tabular}{|c|c|c|}
\hline Characteristics & Mean \pm SD & $n(\%)$ \\
\hline MMSE Score & $24.9(4.3)$ & \\
\hline \multicolumn{3}{|l|}{ Sex } \\
\hline Male & & $40(51.9)$ \\
\hline Female & & $37(48.1)$ \\
\hline Age (years) & $57.3(17.2)$ & \\
\hline \multicolumn{3}{|l|}{ Skin color } \\
\hline White & & $19(24.7)$ \\
\hline Black & & $13(16.9)$ \\
\hline Brown & & $44(57.1)$ \\
\hline Yellow & & $1(1.3)$ \\
\hline \multicolumn{3}{|l|}{ Marital status } \\
\hline Single & & $19(24.7)$ \\
\hline Married & & $37(48.1)$ \\
\hline Divorced/separated & & $8(10.4)$ \\
\hline Widowed & & $5(6.5)$ \\
\hline Living with a partner & & $8(10.4)$ \\
\hline \multicolumn{3}{|l|}{ Schooling } \\
\hline Illiterate & & $11(14.3)$ \\
\hline 1 to 8 years, unfinished & & $27(35)$ \\
\hline 8 or more years & & $39(50.7)$ \\
\hline Individual income (MW)* & 1.333.0(1.616.3) & \\
\hline$\leq 1$ & & $42(54.4)$ \\
\hline Greater than 1 up to 2 & & $21(27.3)$ \\
\hline$>2$ & & $14(18.3)$ \\
\hline \multicolumn{3}{|l|}{ Has a caretaker } \\
\hline Yes & & $54(70.1)$ \\
\hline No & & 23(29.9) \\
\hline \multicolumn{3}{|l|}{ Who the caretaker is } \\
\hline Spouse & & 19(35.2) \\
\hline Child & & 16(29.6) \\
\hline Other & & 19(35.2) \\
\hline \multicolumn{3}{|l|}{ Stroke type } \\
\hline Ischemic & & $49(63.6)$ \\
\hline Hemorrhagic & & 22(28.6) \\
\hline No answer & & $6(7.8)$ \\
\hline \multicolumn{3}{|l|}{ Had a stroke before } \\
\hline Yes & & $15(19.5)$ \\
\hline No & & $62(80.5)$ \\
\hline Hospitalization (days) & 20.42(25.42) & \\
\hline No & & $2(2.6)$ \\
\hline 1 & & $3(3.8)$ \\
\hline $2-7$ & & $21(27.3)$ \\
\hline $8-15$ & & 24(31.2) \\
\hline$>15$ & & $25(32.5)$ \\
\hline No answer & & $2(2.6)$ \\
\hline \multicolumn{3}{|l|}{ Risk factors } \\
\hline Systemic high blood pressure & & $56(72.7)$ \\
\hline Diabetes & & $12(15.6)$ \\
\hline Cardiopathies & & $16(20.8)$ \\
\hline Dyslipidemia & & $37(48.1)$ \\
\hline Sedentariness & & $56(72.7)$ \\
\hline Smoking & & $25(32.5)$ \\
\hline Frequent intake of alcohol & & $28(36.4)$ \\
\hline \multicolumn{3}{|l|}{ Sequelae } \\
\hline Left-sided hemiparesis & & $30(39)$ \\
\hline Right-sided hemiparesis & & $32(41.6)$ \\
\hline Right-sided hemiplegia & & $6(7.8)$ \\
\hline Visual impairment & & $9(11.7)$ \\
\hline Speech impairment & & $22(28.6)$ \\
\hline
\end{tabular}

*When this study was conducted, the minimum wage in Brazil was BRL 724; SD - standard deviation; MMSE - Mini-Mental State Examination; MW - minimum wage
Table 2. Stroke Specific Quality of Life Scale (SS-QOL) scores applied to people who suffered a stroke $(n=77)$

\begin{tabular}{lcc}
\hline Health-related quality of life-SS-QOL & $\begin{array}{c}\text { Mean } \pm \text { SD } \\
\text { Total score per domain }\end{array}$ & $\begin{array}{c}\text { Mean } \pm \text { SD } \\
\text { Score per answer }\end{array}$ \\
\hline Domain personal care & $17.0(5.2)$ & $3.4(1.1)$ \\
Domain sight & $12.8(2.6)$ & $4.3(0.9)$ \\
\hline Domain language & $18.8(5.5)$ & $3.8(1.1)$ \\
Domain mobility & $17.79(7.5)$ & $3.3(1.0)$ \\
\hline Domain work/productivity & $8.6(3.5)$ & $2.9(1.2)$ \\
Domain upper members' function & $14.9(5.4)$ & $3.0(1.1)$ \\
\hline Domain way of thinking & $9.0(3.6)$ & $3.0(1.2)$ \\
Domain behavior & $7.7(4.3)$ & $2.6(1.4)$ \\
Domain stamina & $14.2(5.5)$ & $2.8(1.1)$ \\
Domain family relations & $7.3(3.7)$ & $2.4(1.2)$ \\
Domain social relations & $10.6(5.3)$ & $2.1(1.1)$ \\
Domain energy & $8.1(4.2)$ & $2.7(1.4)$ \\
Total score - Health-related quality of life & $146.8(36.3)$ & $3.1(0.8)$ \\
\hline SD - standard deviation & &
\end{tabular}

Table 3. Association between characteristics of people who suffered a stroke and health-related quality of life score $(n=77)$

\begin{tabular}{|c|c|c|c|c|}
\hline Variables & $\mathrm{n}$ & $H R Q L^{* *}$ & Statistic & $\mathrm{p}$-value \\
\hline MMSE score & 77 & & $0.4^{*}$ & 0.0 \\
\hline Sex & & & $-0.3 \dagger$ & 0.8 \\
\hline Female & 37 & $145.7(39.6)$ & & \\
\hline Male & 40 & $147.9(33.5)$ & & \\
\hline Age & & & $-0.2 \ddagger$ & 0.1 \\
\hline Skin color & & & $1.2 \ddagger$ & 0.3 \\
\hline White & 19 & $157.7(43.6)$ & & \\
\hline Black & 13 & $148.4(31.3)$ & & \\
\hline Brown & 44 & $142.2(34.3)$ & & \\
\hline Marital status & & & $1.1 \dagger$ & 0.3 \\
\hline Married & 37 & $152.3(40.7)$ & & \\
\hline Not married & 40 & $143.0(32.8)$ & & \\
\hline Schooling & & & $6.4 \S$ & 0.0 \\
\hline Illiterate & 11 & $131.3(24.3)$ & & \\
\hline 1 to 8 years, unfinished & 27 & $133.5(29.5)$ & & \\
\hline 8 or more years & 39 & $160.5(38.7)$ & & \\
\hline Monthly individual income (MW) & & & $0.1^{*}$ & 0.3 \\
\hline$\leq 1$ & 42 & $144.2(36.6)$ & & \\
\hline$>1$ up to 2 & 21 & $139.3(36.5)$ & $2.1 \S$ & 0.1 \\
\hline$>2$ & 9 & $158.6(31.6)$ & & \\
\hline Type of stroke & & & $-1.3+$ & 0.2 \\
\hline Ischemic & 49 & $142.2(34.2)$ & & \\
\hline Hemorrhagic & 22 & $154.9(42.2)$ & & \\
\hline Had a stroke before & & & $-0.8+$ & 0.4 \\
\hline Yes & 15 & $140.2(38.8)$ & & \\
\hline No & 62 & $148.5(35.8)$ & & \\
\hline Hospitalization days & & & $0.1 \dagger$ & 0.5 \\
\hline Sequelae & & & & \\
\hline Left-sided hemiparesis & & & $-0.5+$ & 0.6 \\
\hline Yes & 30 & $144.1(37.8)$ & & \\
\hline No & 47 & $148.6(35.7)$ & & \\
\hline Right-sided hemiparesis & & & $2.0+$ & 0.0 \\
\hline Yes & 32 & $156.4(35.3)$ & & \\
\hline No & 45 & $140.0(35.8)$ & & \\
\hline Variables & $\mathrm{n}$ & $H R Q L^{\star \star}$ & Statistic & $\mathrm{p}$-value \\
\hline Left-sided hemiplegia & & & $-2.1 \dagger$ & 0.0 \\
\hline Yes & 6 & $118.2(26.5)$ & & \\
\hline No & 71 & $149.27(36.1)$ & & \\
\hline
\end{tabular}




\begin{tabular}{|c|c|c|c|c|}
\hline Variables & $\mathrm{n}$ & $H R Q L^{* *}$ & Statistic & $\mathrm{p}$-value \\
\hline Sight impairment & & & $-0.6 \dagger$ & 0.1 \\
\hline Yes & 9 & $140.0(28.1)$ & & \\
\hline No & 68 & $147.8(37.3)$ & & \\
\hline Speech impairment & & & $-2.2 \dagger$ & 0.0 \\
\hline Yes & 22 & $134.7(26.7)$ & & \\
\hline No & 55 & $151.7(38.7)$ & & \\
\hline Other sequelae & & & $-1.3 \dagger$ & 0.2 \\
\hline Yes & 13 & $135.2(36.1)$ & & \\
\hline No & 64 & $149.2(36.2)$ & & \\
\hline \multicolumn{5}{|l|}{ Risk factors } \\
\hline Systemic high blood pressure & & & $-1.6 \dagger$ & 0.1 \\
\hline Yes & 56 & $142.8(34.2)$ & & \\
\hline No & 21 & $157.8(40.2)$ & & \\
\hline Diabetes & & & $-0.9 \dagger$ & 0.4 \\
\hline Yes & 12 & $140.0(25.0)$ & & \\
\hline No & 65 & $148.1(38.0)$ & & \\
\hline Cardiopathies & & & $-0.2 \dagger$ & 0.8 \\
\hline Yes & 16 & $145.2(33.4)$ & & \\
\hline No & 61 & $147.3(37.3)$ & & \\
\hline Dyslipidemia & & & $-2.2 \dagger$ & 0.0 \\
\hline Yes & 37 & $137.7(31.4)$ & & \\
\hline No & 40 & $155.4(38.8)$ & & \\
\hline Sedentariness & & & $-0.6+$ & 0.6 \\
\hline Yes & 56 & $145.4(37.1)$ & & \\
\hline No & 21 & $150.6(34.7)$ & & \\
\hline Smoking & & & $-0.4 \dagger$ & 0.7 \\
\hline Yes & 25 & $144.7(38.9)$ & & \\
\hline No & 52 & $147.9(35.4)$ & & \\
\hline Frequent alcohol use & & & $-0.6 \dagger$ & 0.6 \\
\hline Yes & 28 & $143.5(40.4)$ & & \\
\hline No & 49 & $148.8(34.0)$ & & \\
\hline
\end{tabular}

Values in numbers, mean \pm standard deviation, and statistic test values; ${ }^{*}$ Spearman's Correlation; $\uparrow$ Student's t tes of two independent samples; ‡ Pearson's correlation; $\S$ Analysis of Variance; $95 \%$ confidence interval; $\alpha=0.05$; 9 when this study was conducted, MW was BRL 724; MW - minimum wage; * $\mathrm{HRQOL}$ - health-related quality of life

\section{Discussion}

Among the limitations of this study, authors highlight its cross-sectional approach, which did not allow to establish a cause and effect relationship, and a high sample loss because of cognitive deficit, which hindered a generalization of the results found.

Nursing has a significant impact on recovery after a stroke. At the data collection site, the illness sequelae were the most important causes for rehabilitation; therefore, assessing health-related quality of life can provide a global profile of functional and psychosocial conditions, as well as the perception of life by subjects. That can improve both this process and the perception of health-related quality of life, enabling the creation of resources and policies for improved quality in primary care.

Assessing health-related quality of life in people with various illnesses has been a frequent research topic; nevertheless, the increase in survival rates has not been proportional to the maintenance of the same quality of life found before the illness. One of the events which can significantly compromise people's daily lives is the occurrence of strokes, due to their limiting potential on both physical and emotional aspects. ${ }^{(6)}$

A stroke is one of the main determining factors of cognitive decline. In this study, the mean found at the MMSE among the 104 initial participants was 23.1 points $( \pm 5.54)$, a different value compared to that of another study that found a lower mean. ${ }^{(11)} \mathrm{In}$ this sample, $26 \%$ had cognitive deficit, a lower value than the $45 \%$ prevalence of patients with this type of deficit found in literature. ${ }^{(12)}$ These results can be attributed to the fact that this study's participants had more years of schooling than those found in similar research, which influences an increase in scoring.

The population more often affected by strokes comprises older black men, more commonly older than 65 years of age. ${ }^{(4-6,13,14)}$ In this study, there was a predominance of brown men and mean age was lower (57.3 years). This may reflect the regional population characteristics. ${ }^{(15)}$

The presence of the family and the existence of a spouse are essential for sharing a stroke's enormous negative impact on survivors' lives and aid in the demand for care. In this study, married men were the majority $(48.1 \%)$ as in similar studies. ${ }^{(4,16)}$

In other research conducted with survivors, schooling is usually low or none. ${ }^{(17,18)}$ Low schooling and lack of information on this illness consist of risk factors for its occurrence. ${ }^{(18)}$ In this study, however, $50.7 \%$ of the sample had eight years or more of schooling.

The occurrence of stroke is influenced by social and economic conditions. The lack of access to information and health care services can increase the possibility of being ill. Consequently, studies found survivors who earn one minimum wage or less. ${ }^{(6,18)}$ Similarly, most of this study's participants had low income, which is compatible with the fact that the data collection site was exclusive for Unified Health System users.

Family engagement is crucial in the process of illness. In this research, it was evident that most 
survivors counted on a caretaker (70.1\%), who was often a spouse $(35.2 \%)$. In this sense, informal care for patients at home is usually performed by family members. ${ }^{(6)}$

Ischemic strokes occur in about $85 \%$ of the cases and hemorrhagic strokes account for $15 \%$ of the total. ${ }^{(2)}$ In this study, hemorrhagic strokes were predominant. This may be related to the fact that participants were undergoing rehabilitation treatment after they were affected by this type of stroke, often the cause of sequelae and death.

Risk factors increase the probability of occurrence of this illness. Participants of this study had various risk factors previous to the occurrence of the stroke, especially high blood pressure, dyslipidemia, and sedentariness, which correspond to what is found in literature. ${ }^{(2)}$

A significant percentage of survivors had some type of impairment after the first episode of the illness, which caused dissatisfaction with life and various functional limitations. The most common sequelae in this study were right-sided hemiparesis (41.6\%), left-sided hemiparesis (39\%), and difficulty of speech $(28.6 \%)$. Similarly, other research found mobility and speech sequelae among the most common ones. ${ }^{(4,6,19)}$

As far as health-related quality of life is concerned, the total score obtained in the SS-QOL had a mean of $146.84( \pm 36.3)$. A German study established scores below $60 \%$ ( $<147$ points) as low quality of life, the same criterion adopted in this study. ${ }^{(20)}$ Thus, health-related quality of life was undermined. In the case of chronic illnesses and their sequelae, health-related quality of life is generally affected and tends to be jeopardized. ${ }^{(6)}$ A study conducted in another state of Brazil's northeast region found a mean that was slightly above the one found in this study

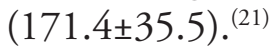

Regarding the mean scores related to answers obtained in terms of general health-related quality of life, this study confirms the results of others, highlighting the damage caused by a stroke. ${ }^{(4,19)}$ Nonetheless, American longitudinal studies reached higher means. ${ }^{(22,23)}$

The most impaired domains in terms of health-related quality of life were social relations
(2.1) and family relations (2.4). The least impaired ones were sight (4.3) and language (3.8) - SS-QOL dimensions among the most and least impaired domains, which is consistent with results observed in literature. ${ }^{(4,6,19,24)}$

Strokes and their sequelae harm or prevent people from fully resuming their work and social activities, justifying the damage to the social relations domain. After the occurrence of this illness, people often find themselves in situations of incapacity and dependence and in need of a caretaker, who is usually a family member. Such fact, in addition to the possible dropout from the work market, abandonment of daily activities, and consequent income reduction may explain the damage in the family relations domain.

When associating the MMSE scores with health-related quality of life, higher MMSE scores were seen associated with higher scores in health-related quality of life. Cognitive deficit is one of the important sequelae of stroke, which may impact on the quality of life of people who suffered it. ${ }^{(25)} \mathrm{A}$ better cognitive state positively impacts one's quality of life.

When it comes to the association between sociodemographic and economic data and health-related quality of life, it was seen that low schooling impacts negatively on quality of life. People with less schooling usually have less information about this illness and about the health care network existing for their care and rehabilitation; consequently, their access to these services is damaged and this has negative repercussions for their job and income opportunities, which may justify their lower health-related quality of life.

In the comparison between the clinical characteristics and total health-related quality of life scores, a statistically significant difference was seen in the variables dyslipidemia, left-sided hemiplegia, right-sided hemiplegia, and speech impairment.

Dysplidemic people have a greater risk of developing atherosclerosis, ${ }^{(26)}$ which, in turn, is a risk factor for other comorbidities. Other comorbidities and the need for closer medical follow-up, additionally to more restrictive diets and wider use of medicines combined with low income, may explain lower health-related quality of life among people with this risk factor. 
Mobility changes are seen among the consequences of stroke. People's ability to move around the environment is a prerequisite for them to perform activities of daily living and keep their independence. ${ }^{(27)}$ Thus, the presence of left-sided hemiplegia implies in reduced health-related quality of life. On the other hand, a contradictory and new finding of this study was that hemiplegics of the right hemibody had better health-related quality of life in comparison with those without this sequela.

Brain injuries caused by a stroke can also determine sequelae to verbal and writing language skills. That, in turn, can produce communication difficulties, causing social isolation which unchains or aggravates depression and thus interferes with quality of life. ${ }^{(28)}$

\section{Conclusion}

Health-related quality of life specifically among people who suffered a stroke decreases after its occurrence and is associated with some characteristics. Lower schooling, additionally to the occurrence of dyslipidemia, left-sided hemiplegia, and speech impairments contributed for its damaging. Higher scores on the MMSE, however, were related to better scores in terms of quality of life.

\section{Acknowledgments}

To the Coordination for the Improvement of Higher Education Personnel (CAPES; Master's scholarship granted to Mary Ângela de Oliveira Canuto).

\section{Collaborations}

Canuto MAO, Nogueira LT, and Araújo TME state that they contributed for the study concept and project, data analysis and interpretation, writing of this article, relevant critical review of its intellectual content, and final approval of the version to be published.

\section{References}

1. World Stroke Organization. World Stroke Campaign. 1 in 6 people worldwide will have a stroke in their lifetime. Campaign Resources. 2012 [cited 2015 Oct 14]. Available from: http://www.world-stroke. org/advocacy/world-stroke-campaign.
2. Smeltzer SC, Bare BG, Hinkle JL, Cheever KH. Brunner e Suddarth: tratado de enfermagem médico-cirúrgica. 12a ed. Rio de Janeiro: Guanabara Koogan; 2011.

3. Seild EM, Zannon CM. Qualidade de vida e saúde: aspectos conceituais e metodológicos. Cad Saúde Pública. 2004; 20(2):580-8.

4. Lima ML, Santos JL, Sawada NO, Lima LA. Qualidade de vida de indivíduos com acidente vascular encefálico e de seus cuidadores de um município do Triângulo Mineiro. Rev Bras Epidemiol [Internet]. 2014 [citado 2015 Oct 2];453-64. Disponível em: http://www.scielosp.org/ pdf/rbepid/v17n2/pt_1415-790X-rbepid-17-02-00453.pdf.

5. Froes KS, Valdes MT, Lopes DP, Silva CE. Factors associated with health-related quality of life for adults with stroke sequelae. Arq NeuroPsiquiatr 2011; 69(2-B): 371-6.

6. Rangel ES, Belasco AG, Diccini S. Qualidade de vida de pacientes com acidente vascular cerebral em reabilitação. Acta Paul Enferm. 2013; 26(2):205-12.

7. Brasil. Ministério da Saúde. Secretaria de Atenção à Saúde. Departamento de Atenção Básica. Envelhecimento e saúde da pessoa idosa [Internet]. Brasília (DF): Ministério da Saúde; 2007 [cited 2015 Oct 2]. Disponível em: http://bvsms.saude.gov.br/bvs/publicacoes/ abcad19.pdf.

8. Bertolucci PH, Brucki SM, Campacci SR, Juliano Y. O Mini-Exame do Estado Mental em uma população geral: impacto da escolaridade. Arq Neuro-Psiquiatr. 1994; 52(1):1-7.

9. Lima RC, Teixeira-Salmela LF, Magalhães LC, Gomes-Neto M. Propriedades psicométricas da versão brasileira da escala de qualidade de vida específica para acidente vascular encefálico: aplicação do modelo Rasch. Rev Bras Fisioter. 2008; 12(2):149-56.

10. Oliveira MR, Orsini M. Escalas de avaliação da qualidade de vida em pacientes brasileiros após acidente vascular encefálico. Rev Neurocienc. 2009; 17(3):255-62.

11. Costa FA, Silva DL, Rocha VM. Estado neurológico e cognição de pacientes pós-acidente vascular cerebral. Rev Esc Enferm USP. 2011; 45(5):1083-8.

12. Brasil. Ministério da Saúde. Secretaria de Atenção à Saúde. Departamento de Ações Programáticas Estratégicas. Diretrizes de atenção à reabilitação da pessoa com acidente vascular cerebral. Brasília (DF): Ministério da Saúde; 2013.

13. Canuto MA, Nogueira LT. Acidente vascular cerebral e qualidade de vida: uma revisão integrativa. Rev Pesq Cuid Fundam. 2015; 7(2):2561-8.

14. Hunger M, Sabariego C, Stollenwerk B, Cieza A, Leidl R. Validity, reliability and responsiveness of the $E Q-5 D$ in German stroke patients undergoing rehabilitation. Qual Life Res. 2012; 21(7):1205-16.

15. Instituto Brasileiro de Geografia e Estatística (IBGE). Censo Demográfico 2010: Teresina [Internet]. 2010 [cited 2015 Oct 2]. Available from:http://www.cens02010.ibge.gov.br.

16. Delboni MC, Malengo PC, Schimidt EP. Relação entre os aspectos das alterações funcionais e seu impacto na qualidade de vida das pessoas com sequelas de acidente vascular encefálico (AVE). Mundo Saúde. 2010; 34 (2):165-75.

17. Moreira NR, Andrade AS, Ribeiro KS Nascimento JA, Brito GE. Quality of life of individuals affected by stroke. Rev Neurocienc. 2015; 23(4):530-7.

18. Leite HR, Nunes AP, Corrêa CL. Perfil epidemiológico e qualidade de vida dos pacientes acometidos por acidente vascular encefálico. Arq Ciênc Saúde UNIPAR. 2011; 15(1):15-21.

19. Chou C. Determinants of the health-related quality of life for stroke survivors. J Stroke Cerebrovasc Dis. 2015; 24(3):1-8. 
20. Gorenstein C, Andrade LH. Beck depression inventory: psychometric properties of the portuguese version. Rev Psiquiatr Clin (São Paulo). 1998; 25(5): 45-50.

21. Monteiro RB, Laurentino GE, Melo PG, Cabral DL, Correa JC, Teixeira-Salmela LF, et al. Medo de cair e sua relação com a medida da independência funcional e a qualidade de vida em indivíduos após Acidente Vascular Encefálico. Ciênc Saúde Coletiva. 2013; 18(7):2017-27.

22. Gillard PJ, Sucharew H, Kleindorfer D, Belagaje S, Varon S, Alwell K, et al. The negative impact of spasticity on the health-related quality of life of stroke survivors: a longitudinal cohort study. Health Qual Life Outcomes. 2015; 13:159.

23. Wulsin L, Alwell K, Moomaw CJ, Lindsell CJ, Kleindorfer D0, Woo D, et al. Comparison of two depression measures for predicting stroke outcomes. J Psychosom Res. 2012; 72(3):175-9.

24. Cordini KL, Oda EY, Furlanetto LM. Qualidade de vida de pacientes com história prévia de acidente vascular encefálico: observação de casos. J Bras Psiquiatr. 2005; 54(4):312-7.

25. Mendes LM, Neves RF, Ribeiro KS, Brito GE, Lucena EM, Batista $H R$, et al. Estado cognitivo dos usuários com AVE na atenção primária à saúde em João Pessoa-PB. Acta Fisiatr. 2011; 18(4):169-74.

26. Fernandes RA, Christofaro DG, Casonatto J, Codogno JS, Rodrigues $E$, Cardoso $M$, et al. Prevalência de dislipidemia em indivíduos fisicamente ativos durante a infância, adolescência e idade adulta. Arq Bras Cardiol. 2011; 97(4):317-23.

27. Moreira RP, Araujo TL, Pagliuca LM. Limitação da mobilidade física em pacientes após 0 acidente vascular encefálico no domicílio: proposta de um conceito. Rev Rene. 2013; 14(5):920-8.

28. Chaves DB, Costa AG, Oliveira AR, Silva VM, Araujo TL, Lopes MV. Comunicação verbal prejudicada - investigação no período pósacidente vascular encefálico. Rev Rene. 2013; 14(5):877-85. 